\title{
АРХИВНЫЕ ИСТОЧНИКИ ПО ИСТОРИИ ПРАВОСЛАВНЫХ ПРИХОДОВ НА ТЕРРИТОРИИ БЕЛАРУСИ (ВТОРАЯ ПОЛОВИНА 1940-Х - 1980-Е ГГ.): ПРОБЛЕМЫ ИССЛЕДОВАНИЯ И ОБРАБОТКИ ИНФОРМАЦИИ
}

\author{
E. В. Савчик
}

Савчик К. В. Архівні джерела з історії православних парафій на території Білорусі (друга половина 1940-х - 1980-і рр.): проблеми дослідження та обробки інформації. Автором здійснено аналітичний огляд даних офіційних документів, що зберігаються в державних архівах Республіки Білорусь, і запропонований варіант їх систематизації по блоках залежно від змісту. На основі проведеного аналізу також виявлено чинники, що негативно впливають на роботу дослідника 3 архівними джерелами $з$ даної проблематики.

Ключові слова: архів; фонди; документи; православна церква; парафія.

Савчик $\boldsymbol{E}$. В. Архивные источники по истории православных приходов на территории Беларуси (вторая половина 1940-х - 1980-е гг.): проблемы исследования и обработки информации. Автором осуществлен аналитический обзор данных официальных документов, хранящихся в государственных архивах Республики Беларусь, и предложен вариант их систематизации по блокам в зависимости от содержания. На основе проведенного анализа также выявлены факторы, негативно влияющие на работу исследователя с архивными источниками по данной проблематике.

Ключевые слова: архив; фонды; документы; православная церковь; приход.

Sauchyk $K$. $V$. The archival sources on the history of the Orthodox parishes in Belarus (the second half of 1940s-1980s): problems of research and information processing. Author accomplished out an analytical review of the data of official documents kept in the state archives of the Republic of Belarus, and offered a method of their systematization according to the content. Based on the analysis, negative factors affecting the work of researchers with archival sources on the subject are also identified.

Keywords: archive; collections; documents; Orthodox Church; parish.

Выявление особенностей организации, государственной регистрации и деятельности православных приходов в послевоенной Беларуси в рамках поиска новых подходов к изучению конфессиональной политики в СССР было начато белорусскими исследователями еще в 90-е годы XX века, когда преодоление ангажированности советской историографии стало определяющим направлением общего развития исторической науки на всем постсоветском пространстве. В результате актуализации данной проблематики появился ряд научных трудов, в которых были заложены основы современного восприятия государственно-конфессиональных отношений в БССР как части репрессивной политики советского тоталитарного государства ${ }^{1}$.

В начале XXI века учеными был продолжен поиск нового видения проблем церковноприходской жизни в атеистическом обществе и белорусскую историографию обогатили работы, которые стали свидетельством повышения научного интереса к истории родного края, истории Русской православной церкви (далее - РПЦ) в БССР².

Учитывая то, что объективность такого рода исследований возможна только при условии наличия качественной фактографической и достаточно широкой по количеству источниковой базы для изучения отдельных сторон жизни конкретного региона, неотъемлемой частью исследовательского процесса в 1990-е годы и в настоящее время было и остается накопление нового фактического материала через обращение к рассекреченным архивным документам СССР. Также следует отметить, что исследователи обосновывают новые теоретические позиции не только на основе аккумулирования данных впервые выявленных источников, но и предпринимают попытки переосмысления уже введенных в научный оборот документов.

Среди архивных материалов, наиболее широко исследуемых на современном этапе как светскими, так и церковными историками, являются документы Совета па делам РПЦ при СНК СССР (с 1946 г. - при Совете Министров СССР) (далее - Совет по делам РПЦ). Непосредственно деятельности Совета, особенностям формирования его аппара- 
та и взаимодействия с церковными структурами посвящен ряд работ российских авторов $^{3}$. Белорусские исследователи, благодаря созданию в 1943-1944 гг. института уполномоченных Совета по делам РПЦ при всех республиканских органах исполнительной власти и облисполкомах, в том числе и при СМ БССР и при двенадцати белорусских облисполкомах, имеют возможность работать в местных архивах с достаточно обширным пластом официальных документов при разработке регионального аспекта церковной истории ${ }^{4}$.

Фонды местных уполномоченных Совета по делам РПЦ (с 1965 г. - уполномоченных по делам религий) сегодня сформированы во всех областных государственных архивах республики, а также отдельные материалы представлены в зональных архивах городов, которые являлись областными центрами БССР во второй половине 1940-х-1950-е гг. в Государственном архиве Брестской области (фонды 210 и 1482), Государственном архиве Витебской области (фонды 1439 и 4131), Государственном архиве Гомельской области (фонды 1354 и 3441), Государственном архиве Гродненской области (фонды 475 и 478), Государственном архиве Могилевской области (фонды 765 и 2340), Государственном архиве Минской области (фонды 812 и 3196), Зональном государственном архиве в г. Бобруйске (фонд 1094), Зональном государственном архиве в г. Барановичи (фонд 477), Зональном государственном архиве в г. Мозыре (фонд 596), Зональном государственном архиве в г. Молодечно (фонд 896), Зональном государственном архиве в г. Пинске (фонд 679) и Зональном государственном архиве в г. Полоцке (фонд 1221)

Автором была проведена работа по ознакомлению с документами фондов уполномоченных во всех областных архивах и в зональном архиве в г. Мозыре. Выводы по итогам проведенной работы сформулированы в нижеприведенных положениях.

Прежде всего представляется необходимым акцентировать внимание на том, что документы указанных фондов можно условно разделить на несколько блоков.

Первый - переписка уполномоченных с Советом, партийными органами и органами советской власти. Данный блок включает обращения уполномоченных по текущим делам, уточнения отдельных организационных вопросов, разъяснения руководящих органов, сообщения о случаях нарушений в работе некоторых уполномоченных и мерах по недопущению их повторения. В переписку попадали только отдельные исключительные события, которые требовали от уполномоченных быстрого реагирования, поэтому для глубокого изучения разных сторон церковно-приходской жизни этот блок малоинформативен. Его главное исследовательское назначение - предоставить сведения об эффективности исполнения тем или иным уполномоченным своих контролирующих функций, и, соответственно, - о полноте и качестве представленного в других документах (в частности, в отчетах уполномоченных) материала. Например, архивные документы за 1945-1948 годы однозначно свидетельствуют о том, что проведение государственной регистрации православных общин в БССР существенно тормозилось имеющими место организационными сложностями в работе уполномоченных. Так, уполномоченные Совета по делам РПЦ при облисполкомах по своему служебному статусу приравнивались к заведующим отделами, однако их штат, несмотря на значительный объем работы, состоял только из одного человека - самого уполномоченного. Облисполком должен был обеспечить его отдельным помещением и транспортом, выделять необходимые канцелярские принадлежности, но это не всегда могло быть выполнено в условиях тяжелого послевоенного времени и создавало определенные трудности при исполнении ими своих служебных обязанностей ${ }^{6}$. Кроме того, в связи с недостатком ответственных работников, облисполком часто направлял уполномоченных в многодневные командировки, связанные, например, с проведением выборов или лесозаготовками ${ }^{7}$. При этом те небольшие суммы денег, которые выделялись Советом по делам РПЦ для уполномоченных на командировки, перечислялись на счета облисполкомов и использовались не самими уполномоченными, а облисполкомами ${ }^{8}$. В результате уполномоченный на протяжении квартала мог реально посетить не более двух - трех районов по своим непосредственным делам, получая основную информацию для отчетов от председателей райисполкомов и от благочинных, что, безусловно, не могло способствовать качественному выявлению ими незарегистрированных общин ${ }^{9}$. В целом необходимо отметить, что регистрация проводилась неподготовленными для этой сложной работы людьми и при отсутствии существенной помощи как со стороны Совета по делам РПЦ, так и со стороны местных властей. Указан- 
ные факторы делают целью проведения анализа выделенного нами блока архивных документов не накопление сведений описательного характера, а повышение научного уровня уже сделанных исследователем выводов.

Более содержательным по региональному конкретно-историческому контексту является второй блок архивных документов по истории приходской жизни в БССР, который составляют справки, информационные и статистические отчеты уполномоченных. Названные документы содержат сведения о принятии на учет православных общин и снятии их с регистрации; данные о количестве священников в каждой церкви и об их общем количестве отдельно по городам и сельским населенным пунктам; о персональном составе белорусского духовенства; о направлениях деятельности церковных активистов и священников; о количестве культовых зданий и их состоянии; информацию об уровне религиозности населения и активности его участия в проведении религиозных праздников; о случаях хулиганских действий по отношению к верующим и др. Именно в отчетах получил отражение такой вектор работы уполномоченных как контроль за деятельностью представителей клира и прихожан, сбор оперативной информации на местах, выявление фактов проявления излишней (по мнению советского руководства) религиозной активности со стороны священников, членов церковных советов и простых верующих. Так, в отчете уполномоченного по Гомельской области за 1953 год отмечается, что несмотря на то, что большинство верующих составляют женщины среднего и пожилого возраста, на церковные праздники приходят даже молодые женщины с детьми ${ }^{10}$. Также приводятся примеры «компрометирующего» поведения отдельных прихожанок. Например, мать председателя Шарпиловского сельского совета Царенкова оказывала влияние на сына, чтобы он не мешал верующим строить новый молитвенный дом и проводить богослужения монаху Щемелеву ${ }^{11}$; прихожанка церкви в д. Ямполь Речицкого района Чередник Ульяна взяла на себя обязанности делегата и несколько раз обращалась к уполномоченному с требованием открыть церковь верующим ${ }^{12}$ и др. В то же время нельзя не отметить, что следствием целенаправленного характера сбора материалов, содержащихся в данном блоке архивных источников, стала заданная узость их содержательной части, что снижает ее исследовательскую ценность с точки зрения создания комплексной реконструкции церковно-приходской жизни того времени.

Наиболее интересную информацию краеведческого характера содержит третий блок архивных документов, который составляют регистрационные дела религиозных общин. В них по каждой православной общине собраны сведения о составе органов приходского самоуправления в разные периоды ее существования, биографии священников, описи церковного имущества и подробные сведения о техническом состоянии культовых зданий (зачастую с приложением планов и фотографий). Эти источники содержат очень широкий пласт фактического материала: сведения о распределении обязанностей внутри общины; фамилии, имена, отчества всех председателей и членов церковных советов и членов ревизионных комиссий; данные о годе рождения, уровне образования, судимости, месте жительства и роде занятий каждого члена приходского актива. Анализ информации такого рода позволяет расширить поле исследовательской проблематики через определение состава актива православных общин, анализ его половозрастной и социальной структуры.

Таким образом, круг представленных в фондах местных уполномоченных Совета официальных документов значителен как по содержанию (отражены фактически все формы взаимодействия верующих и властных структур, приведены необходимые статистические данные и персональные сведения о священниках и церковных активистах), так и по объему (например, только один фонд уполномоченного Совета по делам РПЦ по Гродненской области (1944-1966) включает 750 архивных дел) $)^{13}$.

Квартальные, полугодовые и годовые отчеты уполномоченных, которые составлялись в четырех экземплярах и представлялись в Совет по делам РПЦ в Москве, уполномоченному по БССР и в местный облисполком, продублированы в фондах Национального архива Республики Беларусь (НАРБ) и в фондах Российского государственного архива новейшей истории (РГАНИ).

Постановления областных, городских и районных комитетов Коммунистической партии Беларуси (КПБ) по вопросам проведения антирелигиозной пропаганды, а также информационные доклады и переписка уполномоченных хранятся также в фондах бывших партийных архивов: 
1) Государственный архив общественных объединений Гомельской области - фонд 144

2) Государственный архив общественных объединений Гродненской области - фонды $1,2,3,9,10,14,15,16,2193,2460,4832,5915$ и 6176 ;

3) Государственный архив общественных объединений Могилевской области - фонды $2,5,9,15,27,29,30,40,45,51,1072,2953,2955,4317$ и $6620^{14}$.

Кроме фондов местных уполномоченных Совета, документы локального характера, которые содержат отдельные сведения о количестве культовых зданий РПЦ, деятельности священников и религиозных настроениях населения, о закрытии церквей и состоянии антирелигиозной пропаганды, в большей или меньшей степени представлены также и во всех фондах органов государственной власти как областных, так и зональных архивов ${ }^{15}$.

Политические настроения репрессированных верующих и духовенства, их взаимоотношения и основные направления взаимодействия вне стен храма нашли отражение на страницах уголовных дел, которые хранятся в фондах архива Комитета государственной безопасности Республики Беларусь ${ }^{16}$.

Все вышеприведенное составляет обоснование выделения архивных источников в качестве фундамента источниковой базы исследований по обозначенной нами проблематике. Вместе с тем, на качество ее формирования значительное влияние оказывают следующие факторы.

Первый фактор - прагматический. Доступность сконцентрированных в государственных архивах документов объективно определяет и оптимальные инструментальные возможности исследователя. При этом отмеченный ранее огромный объем исследуемых материалов, а также их однотипность вынуждают исследователя идти по пути построения обобщающих конструкций на основе отдельно взятых фактов или используя в качестве основы обобщения, сделанные уполномоченными Совета. Безусловно, такой путь целесообразен не только исходя из принципа удобства - обычно он задается самой постановкой цели, которая и диктует выбор средств для ее достижения. В результате только так исследователь получает возможность перевести проблему в ситуацию реализации решений, но полученные таким образом результаты нельзя в полной мере назвать наукоемкими.

Второй фактор - идеологический. Не вызывает споров то, что все официальные документы составлялись государственными служащими на основе целенаправленного, идеологически выверенного отбора материалов в соответствии с требованиями инструкций и других нормативных документов. Именно по этой причине нельзя не признать, что оценочным суждениям, которые присутствуют в названных документах, не хватает объективности. При этом субъективная окраска выводов, которые делает исследователь, позволяет посмотреть на историческую ситуацию с другой стороны, но не снимает субъект-объектную проблему при формулировке выводов проведенного исследования.

Третий фактор - контентусный. Сведения, которые содержат документы уполномоченных, не являются полными и точными ввиду того, что, как следует из объяснений уполномоченными причин своего недостаточно внимательного отношения к выполнению возложенных на них обязанностей, необходимые данные собирались ими обычно в спешке (особенно в первые послевоенные годы), без организационной поддержки, а часто и встречая противодействие представителей руководства обкомов и облисполкомов, которые считали работу уполномоченных несерьезной и ненужной ${ }^{17}$. Из-за этого возникают и проблемы в обработке приведенных в отчетах уполномоченных статистических данных, которые вызваны не только их тенденциозностью и неточностью, но и сегментарностью: уполномоченные собирали не общую информацию о деятельности приходов, а только те сведения, которые требовал предоставить Совет по делам РПЦ. Так, в 1947-1949 гг. все сведения оформляли по доведенным сверху формам № 1-5: «Сведения о количестве религиозных точек», «Сведения о составе православного духовенства», «Сведения о количестве недействующих церковных зданий», «Сведения о православных молитвенных домах, которые находятся в общественных и арендуемых у частных лиц зданиях» и «Сведения о приеме посетителей и поступлении разных заявлений и жалоб на имя уполномоченного» ${ }^{18}$. Такая клишированность подачи материала была призвана упростить его обработку, но на самом деле, наоборот, его усложнила, так как цифры в тексте отчетов и в приложениях, представленных в виде таблиц по названным выше формам, обычно существенно 
различаются. Запутанность в отчетах местных уполномоченных по количеству культовых зданий и наличие пробелов в данных о священниках и церковных активистах отмечал в свое время и уполномоченный по делам РПЦ по БССР ${ }^{19}$. Между тем для определения особенностей деятельности церковно-приходских общин на территории БССР именно собранный уполномоченными фактический материал (сведения о священниках, количестве верующих, состоянии молитвенных зданий и т.д.) представляется наиболее ценным.

Перечень негативных факторов можно было бы продолжить, однако и уже названные свидетельствуют, что при изучении истории православных приходов в БССР использование документов, хранящихся в государственных архивных учреждениях Республики Беларусь, в качестве практически единственного основания источниковой базы не является приемлемым. К сожалению, отсутствие понимания названных исследовательских проблем или их сознательное игнорирование рядом белорусских ученых создали в отечественной историографии ситуацию, когда, несмотря на введение за последние двадцать лет в поле научной аналитики значительного числа архивных источников, сам процесс фактологического накопления в данной научной сфере остался на стадии фрагментарного «выдергивания» из документов фондов уполномоченных Совета по делам РПЦ той или иной информации. Кроме того, специфика представленных в белорусских архивах документов обусловила и акцентирование внимания исследователей главным образом на изучении проблем государственно-церковных взаимоотношений в БССР, а не региональных особенностей налаживания приходской жизни ${ }^{20}$. Как результат - отсутствие фундаментальных монографических работ по истории отдельных приходов, благочиний, епархий, а также по конфессиональной истории территориальных образований и историко-этнографических регионов в пределах БССР. Для воссоздания объективной картины и выявления особенностей жизни православных верующих на территории Белорусского Восточного и Западного Полесья, Поозерья, Понеманья, Поднепровья, Центрального региона требуются более значительные по объему, чем архивные материалы, данные устных источников, опубликованные воспоминания, документы церковных учреждений, и т.п. Сбор и обработка вышеперечисленных источников осложнены как объективными (уничтожение в 1960-е годы приходских документов одновременно с закрытием церквей, временное ограничение возможности сбора информации от самих участников событий, почти полное отсутствие в белорусской литературе биографических очерков церковных деятелей этого периода, произведений мемуарного характера, затруднительность получения широкого доступа к материалам частных архивов и архивов церковных учреждений и др.), так и субъективными (изменение отношения к религии большинством респондентов, высокая степень восприятия ими данной темы как закрытой для обсуждения и др.) факторами. Однако без данных этих источников репрезентативность выборок из документов государственных архивов будет находиться на низком уровне, что не позволит дать объективную картину реальности в исследуемый период.

К наиболее значимым работам, опубликованным белорусскими авторами в этот период, можно отнести: Канфесіі на Беларусі (к. XVIII - XX ст.) / В.В. Грыгор'ева, У.М. Завальнюк, У.І. Навіцкі, А.М. Філатава ; навук. рэд. У.І. Навіцкі. - Мінск: ВП «Экаперспектыва», 1998. - 340 с.; Верашчагіна А.У. Гісторыя канфесій у Беларусі: Мінулае і сучаснасць: дапам. для настаўнікаў / А.У. Верашчагіна, А.В. Гурко. - Мінск: Тэхналогія, 2000. - 157 с. и др.

${ }^{2}$ Напр.: Янушевич И.И. Православная церковь в БССР (1924-1953 гг.) / И.И. Янушевич, А.Л. Ленкевич // Канфесіі на Беларусі: гісторыя, сучаснасць: зб. матэр. міжнар. навук.-практ. канф-цыі (Брэст, 7-8.10.2004 г.). - Брэст: Выд-ва БрДУ, 2005. - С. 278-281 ; Агееў А.Р. Рэлігійнае пытанне на пасляваенных з'ездах камуністычнай парты Беларусі // Религия и общество - 2: актуальные проблемы современного религиоведения: сб науч. трудов / Под общ. ред. В.В. Старостенко, О.В. Дьяченко. - Могилев: МГУ им. А.А. Кулешова, 2007. - С. 159-162 ; Ефимович Е.В. История православия в Беларуси в XX в. // Европа: актуальные проблемы этнокультуры: материалы II Междунар. науч.-теорет. конф., г. Минск, 25.04.2008 г. / Бел. гос. ун-т им. М. Танка; редкол. В.В. Тугай (отв. ред.), А.П. Житко, Г.А. Космач [и др.]. - Минск: БГПУ, 2008. - С. 289-291; Кривонос Феодор (свящеенник). Белорусская Православная церковь в ХХ столетии: спецкурс лекций для Минской Духовной Семинарии. Минск: BPAТА, 2008. - 255 с.; Пальчевский А.И. Первое возрождение Минской духовной семинарии в послевоенные годы (1945-1963 гг.) // Беларусь: государство, религия, общество: материалы Междунар. науч.-практ. конф. (Минск-Жировичи, 7.06.2007 г.) / Нац. акад. наук Беларуси, Ин-т истории, Минск. духовн. академ. им. Святителя Кирилла Туровского; редкол.: протоиерей В. Антоник [и др.]. 
- Минск: Белорус. наука, 2008. - С. 146-150; Гаранскі А. Рэформа прыходскага кіравання 1961 г. і яе наступствы ў Беларусі / А. Гаранскі, С. Мандрык // Беларускі гістарычны часопіс. - 2010. - № 11. - С. 8-16; и др.

${ }^{3}$ См.: Маслова И.И. Совет по делам религий при Совете министров СССР и Русская православная церковь (1965-1991 гг.) // Отечественная история. - 2005. - № 6. - С. 52-65; Чумаченко T.A. Совет по делам Русской православной церкви при СНК (СМ) СССР в 1943-1947 гг.: особенности формирования и деятельности аппарата // Власть и церковь в СССР и странах Восточной Европы. 1939-1958. (Дискуссионные аспекты). - М., 2003. - С. 69-99 ; Ее же. Совет по делам Русской православной церкви при СМ СССР и отношения Московской патриархии с Православными церквами Восточной Европы. 1948-1953 гг. // Свобода совести в России: исторический и современный аспекты: сб. ст. М.; СПб., 2008. - С. 295-311; Ее же. Совет по делам Русской православной церкви при СНК (СМ) СССР. 1943-1965 гг.: автореф. дис. ...д-ра ист. наук: 07.00.02. - М., 2011.

${ }^{4}$ См.: Елисеев А.Б. Актуальные вопросы современной историографии истории православной церкви в БССР (1940-е - начало 1950-х гг.) // Працы гістарычнага факультэта БДУ: навук. зб. - Мінск, 2008. - Вып. 3. - С. 112-117; Адамушко В.И. Документы Национального архивного фонда Республики Беларусь по истории православной церкви // Крещение Руси в судьбах народов Беларуси, России и Украины: выбор цивилизационного пути: материалы Междунар. науч. конф. (Минск, 6-7 июня 2013 г). - Минск, 2013. - С. 30-34; Кулажанка У.Г. Асаблівасці арганізацыі жыцця праваслаўнай царквы ў Беларусі 1944-1948 гг. Па матэрыялах фондаў упаўнаважаных Савета па справах Рускай праваслаўнай царквы пры СНК СССР: да пастаноўкі пытання // Хрысціянства ў гістарычным лёсе беларускага народа: зб. навук. арт.: у 2 ч. - Гродна, 2009. - Ч. 2. - С. 62-68; и др.

5 Документы по истории православной церкви в Беларуси XVIII-XX вв. в фондах государственных архивов Республики Беларусь: межархив. справочник / Авт.-сост. О.А. Добычина [и др.]. - Минск, 2003. - С. 105-113.

6 Зональный государственный архив в г. Мозырь (далее - ЗГАМ), ф. 596, оп. 1, д. 3, л. 18; ЗГАМ, ф. 596, оп. 1 , д. 4 , лл. $31,42$.

7 ЗГАМ, ф. 596, оп. 1, д. 3, л. 18.

8 ЗГАМ, ф. 596, оп. 1, д. 4, л. 42.

9 Там же, лл. 2, 16, 27, 31, 41 .

${ }^{10}$ Государственный архив общественных объединений Гомельской области (далее - ГАООГО), ф. 144 , оп. 60 , д. 77 , л. 19.

${ }^{11}$ Там же, лл. 4-5.

${ }^{12}$ Там же, лл. 34, 42.

13 Документы по истории православной церкви в Беларуси... - С. 107.

14 Там же. - C. $154-164$.

15 Там же. - С. 122-145.

${ }^{16}$ Архив Комитета государственной безопасности Республики Беларусь по Гомельской области, архивные дела № 13093-с, № 17155-с, № 18892-с, № 20622-с.

${ }_{17}^{17}$ Национальный архив Республики Беларусь (далее - НАРБ), ф. 951, оп. 1, д. 13, лл. 10-16.

${ }^{18}$ ГАООГО, ф. 144, оп. 60, д. 8, лл. 8-12, 17-21.

${ }^{19}$ НАРБ, ф. 951, оп. 1, д. 13, лл. 12-13.

${ }^{20}$ См.: Мандрик C.B. Особенности государственной политики по отношению к Русской православной церкви в БССР (1953-1964 гг.) // Вести ин-та совр. знаний. - 2008. - № 1. - С. 17-20; Горанский А.О. Осуществление законодательства о культах в БССР (1965 - середина 1980-х гг.) // Вести ин-та совр. знаний. - 2008. - № 1. - С. 13-16; Бубнов П.В. Административные и экономические формы борьбы с церковью в советское время // Беларусь: государство, религия, общество: материалы Междунар. науч.-практ. конф. (Минск - Жировичи, 7 июня 2007 г.). - Минск, 2008. - С. 60-63; Корнеў П.І. Антырэлігійная барацьба ў Брэсцкай вобласці (1953-1959 гг.) // Канфесіі на Беларусі: гісторыя, сучаснасць: зб. матэрыялаў Міжнар. навук.-практ. канф. (Брэст, 7-8 кастр. 2004 г.). - Брэст, 2005. - С. 34-38; и др. 